\title{
Evaluation of Improved Faba Bean Technology in The Wider-Scale: Lesson from Stakeholders' Participation in Wag-Lasta, Ethiopia
}

\begin{abstract}
Ademe Mihiretu ${ }^{1, a, *}$, Adane Wubet ${ }^{1, b}$
${ }^{1}$ Socioeconomic and Agricultural Extension Research Directorate; Sekota Dry-land Agricultural Research Center: Po. Box 62, Sekota, Ethiopia *Corresponding author

A R T I C L I N F O A B S T R A C T

Research Article

This scale-wide participatory evaluation was designed to assess farmers' technology preference and stakeholders' linkage on top of estimating the advantage and efficiency of improved faba bean technology over the local practice. On-farm experiment and assessment were conducted using 100 farmers who allocate $0.25-0.5$ ha of land in Wag-lasta dryland. Planting and other agronomic

Received : 23/12/2019

Accepted : 26/12/2020 standards were applied as per the technological recommendation. Required quantitative and qualitative data collected at farm and farmer level using quadrants and checklist, respectively. Costbenefit analysis, descriptive and inferential statistics were employed to analyse the quantitative data. Qualitative data such as farmers' technology preference and stakeholders' linkage were assessed in simple ranking matrix and SWOT analysis. The improved faba bean technology provided mean grain yields of 1340 and $590 \mathrm{~kg} \mathrm{ha}^{-1}$ in Lasta and Sekota districts, respectively. It has thus a $31.4 \%$ and $38.9 \%$ yield advantage and penalty over the local practice, in that order $(\mathrm{p}<10 \%)$. The improved technology had a profit of 5.3ETB in Lasta, and below the local practice in Sekota district for each 1ETB investment. Among parameters, improved technology's vegetative performance, seed size and yield were convinced farmers in Lasta district. Therefore, results from the improved technology in both districts would provide lesson for future breeding and adaptation programs to apprehend the desired traits and yield-limiting dynamics accordingly. The SWOT analysis also revealed that some strategies are pertinent to strength actors' linkage in extension system via using strengths and opportunities to overcome weaknesses and threats.

Cost-benefit ratio Faba bean technology Farmers' preference Stakeholder participation SWOT analysis
\end{abstract}

\section{Introduction}

Faba bean (Vicia faba L.) is originated in the near east and is one of the earliest domesticated legumes after chickpea and pea, probably in the late Neolithic period. Faba bean ranks sixth in production among legumes grown in the world. China is the main producing country, followed by Ethiopia, Egypt, Italy, and Morocco (Teklay et al., 2014). In addition to food, faba bean plays a great role in every aspect of Ethiopian life hence the straw and seed used as animal feed, while the straw or haulms used for firewood, green manuring, and silage-making (Tolessa et al., 2015). It has also an important role in soil fertility restoration through fixing the atmospheric nitrogen (Barri and Shitaya, 2013). Faba bean is the first among pulse crops cultivated in Ethiopia and leading protein source for the rural people in their traditional dishes. It is also serves as source of foreign currency to the country (Shiferaw et al., 2013).
In Ethiopia, pulse crops are grown annually on approximately $1652,844.2$ hectares of land, of these, $40.5 \%$ were covered by faba bean, with annual production of 848654.6 ton (Asnakech et al., 2017). In Wag-himra area, faba bean production covers about 51587.9 hectares of land with average productivity of 0.9 -ton $\mathrm{ha}^{-1}$. In Lasta area, on the other hand, it covers 4374.7 hectares of land with the average productivity of 1.1 -ton $\mathrm{ha}^{-1}$, which is lower than the national average (CSA, 2018). In spite of huge area coverage and its importance, the productivity of faba bean in Ethiopia is about 1.9 ton $\mathrm{ha}^{-1}$, far below the crop's potential (5-ton ha-1) worldwide (Metayer, 2004). This may be due to different limiting factors, including inherent low yielding genetic potential of the local cultivars, which are susceptible to diseases, pest and parasitic weed as well as diverse abiotic stresses, and traditional production practices (Anteneh et al., 2018). 
Thus, production complications of faba bean has led to adaptation studies in Wag-lasta areas, through collecting different nationally released improved varieties to increase production and productivity (Temesgen and Aemiro, 2012). Hence, the improved faba bean variety by the name 'Dosha' with its full production package was recommended for Wag-lasta areas having a yield potential ranging between 17.17-2.72 ton ha $^{-1}$ (Yirga and Zinabu, 2019). However, the recommended faba bean technology is not demonstrated as required since stakeholders in the extension system (researchers, extension workers and farmers) have inconsistencies on efficient production practices.

Researchers, thus suggest improved variety with its full production package is inevitable for production enhancement (Yirga and Zinabu, 2019). On the other hand, farmers stacked on local cultivars and existing agronomic practices trusting that insignificant yield difference among the advocated and prevailing once. Moreover, agricultural extension workers believe that, improved varieties are good but spending for package components like fertilizer is wasteful since faba bean is blessed with intrinsic capacity of earning nitrogen from the atmosphere (A. Assefa, Wag-khimra zone bureau of Agriculture, personal communication).

The improved faba bean technology failed to take root among farmers in the dryland areas and remain confined to research stations. Since, the recommendation was explicitly depending on researchers' interest and identified traits, without considering farmers' involvement and context. An increasing number of scientists therefore, recognized that there is a need to modify research methodology in order to make it more sensitive to local conditions (Sanghi, 1987). Further intensification of extension services has not shown great promise in improving the situation due to poor networking among policy, research, extension services and input supplies in technology dissemination (Ashenafi and Woldie, 2015).
Imperfections in the technology dissemination system are generally the result of information diffusion problem (farmers do not know about the technologies), training problem (farmers heard about or even saw the technology but do not know how to implement it), and technology-fit or enabling environment problem (Teame et al., 2017). To circumvent these problems and to achieve better results, responsive adaptive research trials should be established with actively participating farmers under full guidance of extension workers (Ogwal-Kasimiro et al., 2012). In fact, farmers' participation in technology development is costeffective way of identifying farmer-preferred technology and then to ensure the adoption (Tafere et al., 2012). In order to resolve paradoxes in the extension system, the scale wide on-farm evaluation was launched comprising improved faba bean technology in one side and the local cultivar with local practice in the other side.

Therefore, this scale wide participatory evaluation was intended; to compare the relative advantage and efficiency of improved faba bean technology over the local production practice, to assess farmers' preference and demand on the improved technology, to examine and strengthen linkage among possible actors in the extension system to establish sustainable technology multiplication and diffusion.

\section{Materials and Methods}

\section{The Study Area}

This evaluation study was conducted for two consecutive cropping seasons in Sekota and Lasta districts of Wag-lasta, in northeast Amhara region. Sekota district is found at an altitude of 2400 meters above sea level. It has annual mean rainfall and temperature of $774.2 \mathrm{~mm}$ and $28.5^{\circ} \mathrm{C}$, respectively. The dominant soil type of the district is loam and clay soil (Mihiretu et al., 2019). Lasta district on the other hand, located at altitude of 2400 meters above sea level with the annual rainfall of $895.2 \mathrm{~mm}$ and average temperature of $26.2^{\circ} \mathrm{C}$. The dominant soil type of the district is black sandy and loam (WOA, 2018).

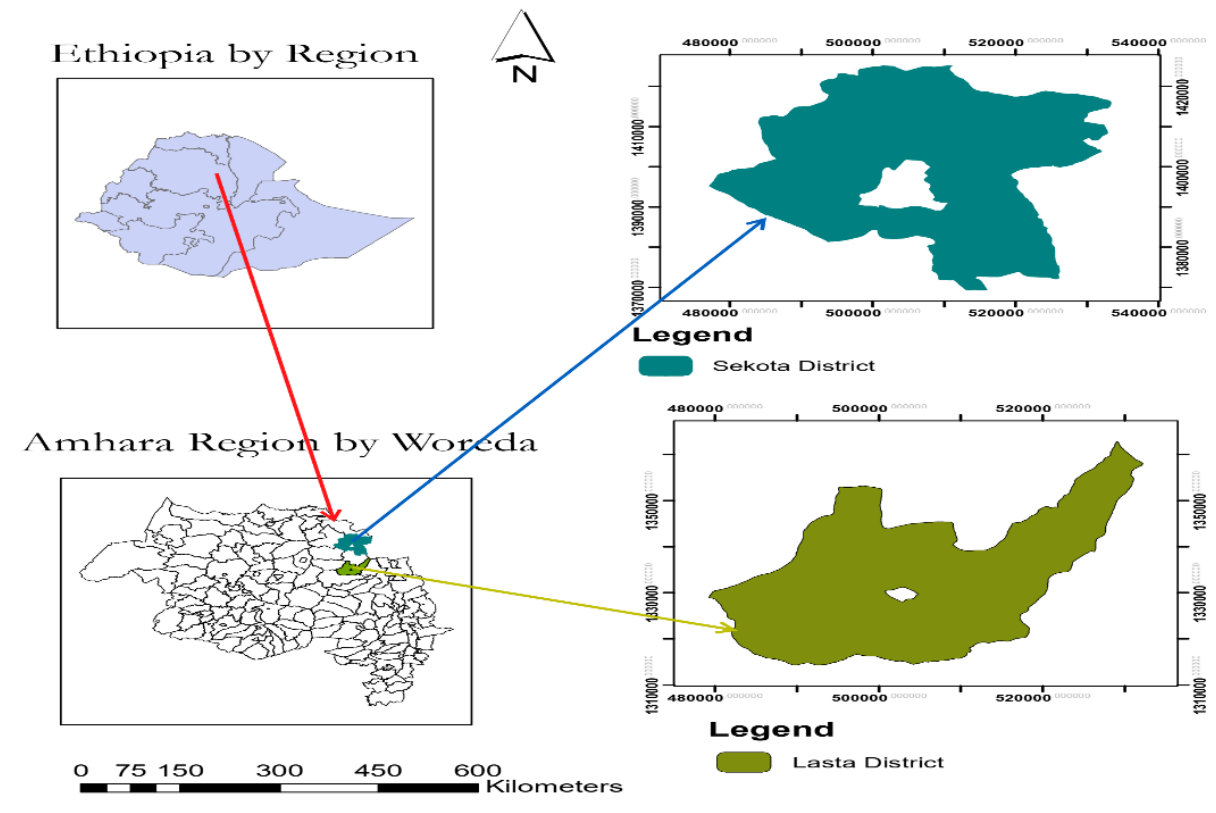

Figure 1. Map of the study locations 
Table 1. Duties and responsibilities of key stakeholders in faba bean technology evaluation

- $\quad$ Prepare technical manuals and provide training for farmers

- Confirm selected farms and deliver in puts on time

- Provide technical support to farmers and experts

- Organize field days with district Agriculture offices

- Participate in trainings and field days

- Provide technical support in farm and farmer selection

- Follow up and monitoring the activities

- Identify farmers and clustered farmlands

- Provide technical support in technology application

- Provide information to researchers on disease outbreaks

- Facilitate farmers' seed exchange system

- Prepare farmland to the required (optimum) level

Participant farmers $\quad$ - Planting, weeding and harvesting on time and properly

- Maintain seed quality to give back to the source center

- Exchange the seed to interested farmers in any arrangement

Note: DAs, Development Agents; SMSs, Subject Matter Specialists

\section{Sampling and Experimental Procedure}

Multi-stage sampling method was employed to select participant farmers. In the first stage, Wag-lasta area was purposively selected to denote faba bean production areas under moisture deficient scenario. In the second stage, Sekota and Lasta districts from Wag-lasta areas purposively selected on the bases of accessibility and production potential. In third stage, two kebeles (the smallest administrative unit in Ethiopia) per district identified randomly consisting 50 farmers who had 0.25 0.35 ha clustered farmland on average. In combination, 100 (25-female) farmers were selected to host on farm evaluation trial. Key stakeholders identified and signed memorandum of understanding (MoU) to part duties in the entire evaluation process (Table 1). Clustering was preferred to avoid varietal crossing risks as well as to inspire and attract farmers' technology adoption. Farmers then provided training on basic agronomic practices to create awareness on improved faba bean technology and the extension approach in general. Planting was in row at $200 \mathrm{~kg} \mathrm{ha}^{-1}$ seed rate with $100 \mathrm{~kg} \mathrm{ha}^{-1}$ fertilizer (NPS), whereas other management practices were done as per the recommendation. The evaluation carried out for two consecutive years to minimize risks of seasonal variation as well as to upsurge farmers' confidence on the technology. Finally, field days were held involving stakeholders to evaluate and endorse the technology's performance to the wider community.

\section{Data Collection And Analysis}

Both quantitative and qualitative data including the sociodemographic features of sample farmers were collected. The quantitative data such as grain yield from sample farmlands were collected using quadrant. The collected data were analyzed in descriptive statistics such as measures of central tendency like mean, percentages, and frequency. Paired sample t-test was used to note the yield significance among the improved technology and local practice. The yield advantage that quantifies the change between improved technology and local practice was calculated using the following formula (1). The technological and extension gaps as well as technological index were also calculated using the formula (2), (3) and (4) provided below (Mihiretu et al., 2019).

$$
\begin{aligned}
& \Delta \mathrm{Y}=\frac{\mathrm{Ys}-\mathrm{Yb}}{\mathrm{Yb}} \times 100 \\
& \mathrm{TG}=\mathrm{Ys}-\mathrm{Yb} \\
& \mathrm{EG}=\mathrm{PY}-\mathrm{Ys} \\
& \mathrm{TI}=\frac{\mathrm{TG}}{\mathrm{PY}} \times 100
\end{aligned}
$$

Where: $\Delta \mathrm{Y}=$ change of yield, $\mathrm{Ys}=$ yield of improved technology, $\mathrm{Yb}=$ local practice yield, $\mathrm{PY}=$ potential yield, $\mathrm{TG}=$ technological gap, $\mathrm{EG}=$ extension gap and $\mathrm{TI}=$ technology index.

The cost-benefit analysis is a useful tool in determining the profitability of one technology over the other (Daniel et al., 2009). Variable cost is the cost that varies with changes in output while total revenue is total income obtained through multiplying the quantity sold by unit price.

A technology, which has greater than one benefit cost ratio, is considered as profitable. Thus, to assess the profitability of improved faba bean technology over the control, the following economic variables were calculated.

$\mathrm{GM}=\mathrm{TR}-\mathrm{TVC}$

$$
\mathrm{BCR}=\frac{\mathrm{TR}}{\mathrm{TVC}}
$$

Where, $\mathrm{GM}=$ gross margin, $\mathrm{TR}=$ total revenue, $\mathrm{TVC}=$ total variable cost and $\mathrm{BCR}=$ benefit cost ratio.

To elicit farmers' faba bean technology preference, two steps were followed. First, list of attributes that help farmers to characterize different faba bean technologies were identified.

These attributes included grain yield, grain size, number of pods per plant, early maturity, and tolerance to drought. Second, we elicited farmers' perceptions using these attributes for local and improved faba bean production technologies, that currently grown by the farmers themselves. Then, farmer's preference and perception to each comparison technology were analysed in simple ranking method (De Boef and Thijssen, 2007). 


$$
\sum \frac{N}{n}
$$

Where, $\mathbf{N}$ is value given by the group of farmers for each technology based on the selection criteria, and $\mathrm{n}$ is the number of selection criteria used by farmers.

Moreover, participatory SWOT analysis study was conducted using open-ended qualitative-type instrument, to analyse the external and internal environments of key stakeholders in the extension system (Kangas et al., 2003). It was used to indicate and identify stakeholders' strengths and weaknesses as well as opportunities and threats (Figure 2). Stakeholders thus, can develop strategies based on their strengths and vanishing weaknesses, as well as gain maximum profit by using opportunities and neutralizing threats (Ibrahim et al., 2019).

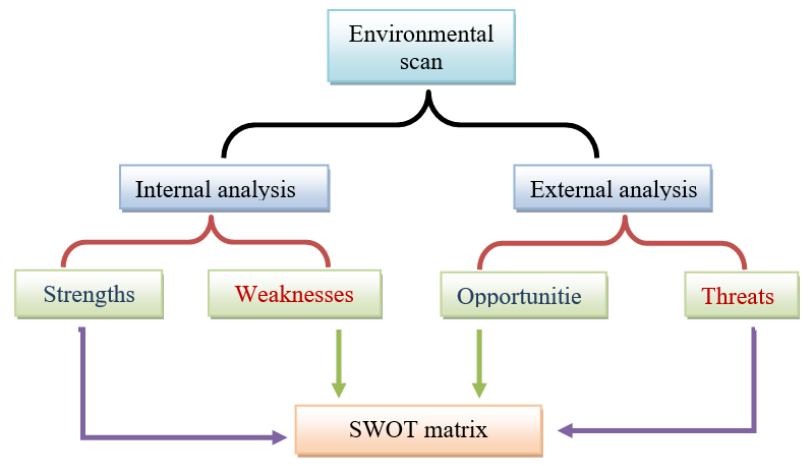

Figure 2. Theoretical framework of SWOT analysis adapted from Ibrahim et al. (2019)

\section{Results and Discussion}

\section{Socio-Demographic Characteristics of Participant Farmers}

Most farmers were male-headed households with an average age of 43.7 and 17.5 years farming experience. Participant farmers were thus in active age group and able to understand changes in farming and production system across time. Average family size of the household was 4.5, which indicates the presence of sufficient labor for full technology package application. Farmers' educational status determines extension internalization and technology application; hence, $53 \%$ of participant farmers were literate from read and write to secondary school levels. Participant households allocated on average 0.25 ha of land for technology evaluation. Despite all farmers were provide technical training, $96.8 \%$ of them were agreed that the training provided was sufficient to apply the technology (Table 2). Agronomic literatures dictate that land tillage frequency, planting and weeding time determines productivity. The agronomic findings on improved faba bean technologies suggested that 'three times tilling is an optimum level' (Yirga and Zinabu, 2019). As a result, $87.5 \%$ of farmers were plowed at sufficient level $(3 \mathrm{x})$, but the rest were plowed below the optimum level due to lack of draft animals in the household. In addition, 94.1 and $91.8 \%$ of farmers were planting and managing the trial at critical and proposed times. Timely planting having adequate soil water together with timely weeding favor fast growth thus allows good yield of faba bean in dry land areas (Shapiro and Sanders, 2002).
Yield Performances And Profitability Analysis of Faba Bean Technology

The average grain yield of improved faba bean technology was 1340 and $590 \mathrm{~kg} \mathrm{ha}^{-1}$ in Lasta and Sekota districts, respectively. The paired t-test value in Table 3 below shows that, the improved technology has a $31.4 \%$ yield advantage over the local cultivar under farmers' existing practice in Lasta district $(\mathrm{P}<5 \%)$. However, the improved technology has a $38.9 \%$ yield penalty over the local practice in Sekota district $(\mathrm{P}<10 \%)$. The technological gap between the improved and local production practices were 320 and $-230 \mathrm{~kg} \mathrm{ha}^{-1}$ for Lasta and Sekota districts, respectively. This finding revealed that the production problem in Lasta, could be overwhelmed by adopting the improved variety with its efficient package components. On the other hand, lower faba bean production in Sekota district is not solved by adopting the improved variety with its full package. The extension gap between the potential yield and improved production technology was 1382.2 and $1607.9 \mathrm{~kg}$ $\mathrm{ha}^{-1}$ in Lasta and Sekota districts, respectively. This finding shows that it was impossible to replicate the yield potential attained by the biological researcher in real farm context. This finding is in disagreement with the results of Yirga and Zinabu (2019), who states that the promising Dosha improved faba bean technology gave the highest grain yield and showed best performance at both Lasta and Sekota districts. The $11.8 \%$ and $-10.5 \%$ technological indexes in Lasta and Sekota districts, respectively. The technology index indicates the feasibility of evolved technology at the farmer's context, so that the lower technological index in Lasta district depicts the feasibility of promoted faba bean technology (Mihiretu et al., 2019). However, the negative technological index in Sekota district presents evidence for further scope in faba bean production and productivity enhancement. To bridge up the gap between technology developed and technology transferred, there is a need to strengthen the extension network on top of providing attention to context specific technological recommendation.

Expenditures, that were similar for both production practices were not taken and analyzed. Hence, given the prevailing farm gate prices, the benefit-cost ratio was computed on hectare basis. Results from farm budget analysis revealed that, the costs of improved and local faba bean production practices were ETB 8130 and 5600, respectively in Lasta district. However, in sekota district, the costs of improved and local production practices were ETB 8780 and 6000, respectively. The farmers were hence able to generate a gross margin of ETB 34,750 and 11,870 from the improved faba bean technology in Lasta and Sekota districts, respectively (Table 4). Likewise, from the local faba bean production practices, the farmers were collecting a gross margin of ETB 22,960 and 18,900 in Lasta and Sekota districts, respectively. Therefore, the cost-benefit ratio result revealed that by adopting the improved faba bean technology, farmers could make the highest profit (ETB 5.3) after covering the cost in Lasta district. However, in Sekota district, adopting the improved faba bean technology was not profitable as if the highest profit (ETB 4.2) was recorded from the local practice after covering the cost. This finding conveys that using improved faba bean technology in Sekota district is not promising and profitable, while in Lasta district the improved faba bean technology was gainful compared to the existing local faba bean production practice. 
Table 2. Characteristics of participant farmers in faba bean technology evaluation in Wag-lasta, $\mathrm{n}=100$

\begin{tabular}{|c|c|c|c|}
\hline Category & Variables & Indicator & Estimates \\
\hline \multirow{10}{*}{ Demographic characteristics } & \multirow{2}{*}{ Gender of the head of the household (\%) } & Male & 82.30 \\
\hline & & Female & 17.70 \\
\hline & \multirow{2}{*}{ Age of the head of the household (years) } & Mean & 43.72 \\
\hline & & Std & 13.41 \\
\hline & \multirow{2}{*}{$\begin{array}{l}\text { Educational level of the head of the } \\
\text { household }(\%)\end{array}$} & Literate & 53.00 \\
\hline & & Illiterate & 47.00 \\
\hline & \multirow{2}{*}{$\begin{array}{l}\text { Farming experience of the head of } \\
\text { household (years) }\end{array}$} & Mean & 17.54 \\
\hline & & Std & 6.32 \\
\hline & \multirow{2}{*}{ Family size of the household } & Mean & 4.53 \\
\hline & & Std & 2.66 \\
\hline \multirow{8}{*}{$\begin{array}{l}\text { Improved faba bean technology } \\
\text { production characteristics }\end{array}$} & \multirow{2}{*}{$\begin{array}{l}\text { Size of land allocated for faba bean } \\
\text { technology (ha) }\end{array}$} & Mean & 0.25 \\
\hline & & Std & 0.14 \\
\hline & \multirow{2}{*}{ Farm tillage frequency $(\%)$} & $\geq 3 x$ & 78.5 \\
\hline & & $<3 x$ & 21.5 \\
\hline & \multirow{2}{*}{ Planting was on time $(\%)$} & Yes & 94.1 \\
\hline & & No & 5.90 \\
\hline & \multirow{2}{*}{$\begin{array}{l}\text { Weed management was on critical time } \\
(\%)\end{array}$} & Yes & 91.8 \\
\hline & & No & 8.20 \\
\hline \multirow{4}{*}{ Access to agricultural services } & \multirow{2}{*}{ The training provided was sufficient $(\%)$} & Yes & 96.80 \\
\hline & & No & 3.20 \\
\hline & \multirow{2}{*}{ The follow up of experts was adequate (\%) } & Yes & 83.82 \\
\hline & & No & 16.18 \\
\hline
\end{tabular}

Source: Own survey, 2017-18, Note: Std, standard deviation

Table 3. Yield performance and gaps of improved and local faba bean production technologies in Wag-lasta area

\begin{tabular}{l|lcccccccc}
\hline \multicolumn{1}{c}{ Districts } & Category & RYI & MY & Std. & T & Sig. & TG & EG & TI \\
\hline \multirow{2}{*}{ Lasta } & Improved & $420-1920$ & 1340 & 3.34 & 2.89 & $0.014^{* *}$ & 320 & 1382.2 & 11.76 \\
& Local & $410-1760$ & 1020 & & & & & & \\
\hline \multirow{2}{*}{ Sekota } & Improved & $380-830$ & 590 & 6.13 & 1.04 & $0.073^{*}$ & -230 & 1607.9 & -10.46 \\
& Local & $540-1220$ & 820 & & & & & & \\
\hline
\end{tabular}

RYI: Range yield index $\left(\mathrm{kg} \mathrm{ha}^{-1}\right)$, MY: Mean yield $\left(\mathrm{kg} \mathrm{ha}^{-1}\right), \mathrm{T}$ : T-value, TG: Technology gap $\left(\mathrm{kg} \mathrm{ha}^{-1}\right)$, EG: Extension gap $\left(\mathrm{kg} \mathrm{ha}^{-1}\right)$, TI: Technological index (\%), Source: Computed from field data, 2017-18, Note: The potential yield of improved faba bean for Lasta and Sekota $=2722.2 \mathrm{and} 2197.9 \mathrm{~kg}$ ha $^{-1}$, Where: TG $=$ IP - LP and EG $=$ PY - IP; TI $=$ TG/PY $\times 100$, [TG, technology gap; IP, improved practice; LP, local practice; EG, extension gap and TI, technology index]

Table 4. Cost-benefit analysis of improved and local faba bean production practices

\begin{tabular}{|c|c|c|c|c|c|c|c|c|}
\hline \multirow{3}{*}{ Cost-benefit items } & \multicolumn{4}{|c|}{ Lasta } & \multicolumn{4}{|c|}{ Sekota } \\
\hline & \multicolumn{2}{|c|}{$\begin{array}{l}\text { Improved } \\
\text { (ETB/ha) }\end{array}$} & \multicolumn{2}{|c|}{ Local (ETB/ha) } & \multicolumn{2}{|c|}{ Improved (ETB/ha) } & \multicolumn{2}{|c|}{ Local (ETB/ha) } \\
\hline & Return & Cost & Return & Cost & Return & Cost & Return & Cost \\
\hline Average yield $\left(\mathrm{kg} \mathrm{ha}^{-1}\right)$ & 1340 & - & 1020 & - & 590 & - & 820 & - \\
\hline Total return (TR) & 42880 & - & 28560 & - & 20650 & - & 24900 & - \\
\hline Costs of seed & - & 6400 & - & 5600 & - & 7000 & - & 6000 \\
\hline Cost of fertilizer & - & 1250 & - & - & - & 1220 & - & - \\
\hline Labor cost & - & 480 & - & - & - & 560 & - & - \\
\hline Total variable cost (TVC) & & 8130 & & 5600 & & 8780 & & 6000 \\
\hline Gross margin, $\mathrm{GM}=\mathrm{TR}-\mathrm{T}$ & $\mathrm{VC}$ & 34750 & & & & 11870 & & \\
\hline Cost-Benefit, CBR $=\mathrm{TR} / \mathrm{T}$ & & 5.3 & & & & 2.4 & & \\
\hline \multicolumn{4}{|c|}{$\begin{array}{l}\text { Note: Average price of fertilizer (NPS) in ETB } / \mathrm{kg}= \\
\text { Cost of improved /local seed in ETB } / \mathrm{kg}= \\
\text { Average local Labor day's pay in } \mathrm{man} / \mathrm{day}= \\
1 \text { ETB }=\text { USD } 27.8\end{array}$} & $\begin{array}{c}12.5 \\
32 / 28 \\
60\end{array}$ & & $\begin{array}{c}12.2 \\
35 / 30 \\
70\end{array}$ & & \\
\hline
\end{tabular}

Farmers' Preference and Demand on Faba Bean Production Technology

Farmers set out criteria to select and rank production practices that best fit their real contexts. Earliness, pod per plant, seed boldness, tolerance to drought and better yield were identified as main criteria. Results from simple ranking matrix, revealed that farmers in Sekota district had no confidence on the improved faba bean technology especially with respect to earliness tolerance to drought and grain yield. However, in Lasta district, $56 \%$ of farmers were interested to use the improved faba bean technology in relatively better moisture conserving sites and land types. Farmers' perception and viewpoint of the technology summarized and presented as positive and negative sides. The positive sides include good germination and vegetative performance, large pod and seed size, higher marketability and better test as well as suitable to the higher moisture context in Lasta district. On 
the other hand, in Sekota district the improved technology was expressed by late flowering, late seed setting performance, late maturing as well as susceptible to diseases and pests (fungal, chocolate spot and ants). At the end of the trial, field days were organized involving different stakeholders (farmers and experts from zonal to district levels). As a result, 190 (31 female) farmers as well as 13 (2 female) experts attended in Lasta district. Likewise, 209 (47 female) farmers and 12 (1 female) experts in Sekota district visited the technologies. The participant farmers and experts as a group were valued the production practices by the overall performance. The farmers finally preferred the improved technology for its vegetative performance, seed boldness and yield performance in Lasta district. Nonetheless, the improved faba bean technology criticized by late maturity, tolerance to drought and low yield performance in Sekota district.

\section{SWOT Analysis of Stakeholders' Linkage}

Appropriate distribution of duties among stakeholders would consolidate the tripartite linkages of farmersexperts-research in the extension system. These actors were therefore, handling tasks to facilitate technology diffusion via continuous follow up, technical support, and consultation. To evaluate and create demand on the technology, field days held involving farmers, experts, and higher officials. The farmers were blaming the clustering approach since it includes all adjacent farms depriving the farm history, soil type and moisture status, this in turn leads to production deviance in inside the cluster. Taking into account all the variables that were discussed above, we can now proceed to SWOT analysis of faba bean technology evaluation. Like many other sectors, faba bean production depends on both internal and external factors. Based on the SWOT analysis, thus there is a need to identify the strengths and weaknesses of the sub-sector and match them with the opportunities and threats of the external environment.

Strengths are the characteristics of the sector that give it an advantage while weaknesses are the opposite and the characteristics that become a disadvantage for faba bean production sub-sector. Opportunities and threats are external conditions, the former being the elements that can be exploited to upsurge the advantage of the sub-sector but the latter is the environmental elements that could cause problems in the sub-sector. Table 6 below, presents an overview of the strengths, weaknesses, opportunities and threats of the faba bean production sub-sector.

Table 5. Farmer's preference criteria on faba bean varieties

\begin{tabular}{l|lcccccccc}
\hline \multirow{2}{*}{ Districts } & Technology & Earliness & $\begin{array}{c}\text { Pod per } \\
\text { plant }\end{array}$ & $\begin{array}{c}\text { Seed } \\
\text { boldness }\end{array}$ & $\begin{array}{c}\text { Drought } \\
\text { tolerance }\end{array}$ & $\begin{array}{c}\text { Better } \\
\text { yield }\end{array}$ & $\begin{array}{c}\text { Total } \\
\text { score }\end{array}$ & Mean & Rank \\
\hline \multirow{2}{*}{ Lasta } & Improved & 3 & 4 & 5 & 2 & 4 & 18 & 3.6 & 1 \\
& Local & 4 & 3 & 2 & 3 & 2 & 14 & 2.8 & 2 \\
\hline \multirow{2}{*}{ Sekota } & Improved & 1 & 3 & 4 & 2 & 2 & 12 & 2.4 & 2 \\
& Local & 4 & 3 & 1 & 5 & 3 & 16 & 3.2 & 1 \\
\hline
\end{tabular}

Source: Our survey, (2017-18)

Table 6. SWOT analysis of actors in faba bean technology evaluation in Wag-lasta

\begin{tabular}{|c|c|}
\hline \multicolumn{2}{|c|}{ Internal } \\
\hline $\begin{array}{l}\text { Strengths } \\
\text { Farmers: } \\
\text { - } \quad \text { Being optimistic and high demand for new technology } \\
\text { - } \quad \text { Preparing their farmland to the required (optimum) level } \\
\text { - } \quad \text { Full technology package application } \\
\text { - } \quad \text { Active participation throughout the trial } \\
\text { - } \quad \text { Exchange the seed to interested farmers in any arrangement } \\
\text { Experts: } \\
\text { - } \quad \text { Select farmers and clustered farmlands for the trial } \\
\text { - } \quad \text { Provide technical support in technology application } \\
\text { - } \quad \text { Provide information to researchers on disease outbreaks } \\
\text { - } \quad \text { Monitor the activities and arrange field days } \\
\text { - } \quad \text { Facilitate farmer to farmer seed exchange system } \\
\text { Researchers: } \\
\text { - } \quad \text { Prepare technical manuals and provide training for farmers } \\
\text { - } \quad \text { Confirm selected farms and deliver in puts on time } \\
\text { - } \quad \text { Provide technical support to farmers and experts } \\
\text { Organize field days with district Agriculture offices }\end{array}$ & $\begin{array}{l}\text { Weaknesses } \\
\text { - } \quad \text { Reluctant to weed at optimum level } \\
\text { - } \quad \text { Problem in maintaining the seed quality } \\
\text { - } \quad \text { Late to pay back the seed to the source center } \\
\text { - } \quad \text { Stumpy technical backup to farmers } \\
\text { - } \quad \text { Meager and poor follow up of activities }\end{array}$ \\
\hline
\end{tabular}
External

\begin{tabular}{l|ll} 
Opportunities & \multicolumn{2}{l}{ Threats } \\
- $\quad$ Existence of NGOs working on technology promotion & $\bullet \quad$ Low and erratic rainfall with high temperature \\
- Improved technology use become focus of the government & $\bullet \quad$ High risk of drought within 3-4 years' frequency \\
- $\quad$ Farmers' have information about the improved technology & $\bullet \quad$ Low willingness of farmers to pay for inputs costs \\
- Existence of seed exchange culture in the community & $-\quad$ Limited and expensive input availability \\
& $-\quad$ Farmers' culture of dependency on food aid \\
\hline
\end{tabular}




\section{Conclusion}

This scale wide participatory evaluation was intended to compare the advantage and efficiency of improved faba bean technology over the local production practice, as well as to examine linkages among possible stakeholders in the extension system. The comparison result hence revealed that the improved faba bean technology had a yield advantage over the local production practice in Lasta district. Farmers were also interested and preferred the improved faba bean technology to use in selected moisture saving black and swampy land types. As a result, 'Dosha' improved faba bean technology was recommended for production in Lasta district, mainly in better moisture conserving soil types and similar agro ecological conditions. However, in Sekota district, the improved technology had a yield penalty over the local practice. According to the preference-ranking analysis result, the farmers did not prefer the improved technology due to its late maturity, meagre drought tolerance and lower yield. The improved technology hence failed to take root among farmers and remain confined to research stations since the technology development process was not involving farmers in general and their real environmental contexts in particular. Therefore, the poor performance of improved faba bean technology as an outcome would provide lesson for researchers to apprehend constraints as a backstop for future breeding and adaptation programs in dry land areas. Moreover, the SWOT analysis output provided that, some relevant strategies are required to strength linkage among possible actors in extension system through using strengths and opportunities to overcome weaknesses and to minimize threats and their effects. The most essential points to be taken to promote linkages among key actors are thus: establishing strong coordination between researchers, experts, farmers and other organizations of common interest; adequate training and expertise advice for farmers and experts starting from strategy design to implementation; as well as providing access to technological inputs on top of credit access for interested farmers. Finally, take the advantage of meteorological web sites to offer to date information for farmers, suit the needs and real contexts of the farmers in technological development, to deal with dry land areas.

\section{Acknowledgment}

The author would like to acknowledge all participant Stakeholders for their unreserved cooperation throughout the evaluation process.

\section{References}

Anteneh A, Yohannes E, Mesganaw G, Solomon G, Getachew T. 2018. Survey of Faba Bean (Vicia Faba L.) Diseases in Major Faba Bean Growing Districts of North Gondar. African Journal of Plant Science, 12 (2): 32-36.

Ashenafi MI, Wolde ME. 2015. Effect of Faba Bean (Vicia Faba L.) Varieties on Yield Attributes at Sinana and Agarfa Districts of Bale Zone, Southeastern Ethiopia. Jordan Journal of Biological Sciences, 8(4): 281-86.
Asnakech T, John D, Julia S, Asnake F. 2017. Participatory Assessment of Production Threats, Farmers Desired Traits and Selection Criteria of Faba Bean (Vicia Faba L.) Varieties. Indian Journal of Agricultural Research, 50 (4): 295-302.

Barri T, Shtaya M. 2013. Phenotypic Characterization of Faba Bean (Vicia faba L.) Landraces Grown in Palestine. Journal of Agricultural Science, 5 (2): 31-39

CSA (Central Statistical Agency). 2018. Ethiopian Agricultural sample survey 2017/18. Report on area and production of crops (private peasant holdings, meher season), Volume I, Addis Ababa, pp, 69-78.

Daniel JD, Ja'afar-Furo MR, Tashkalma AK, Ezekiel CS. 2009. Economic of cotton production in the Southern part of Adamawa State Nigeria. International Journal of Crop Science, 1 (1):75-76.

De Boef WS, Thijssen MH. 2007. Participatory tools working with crops, varieties, and seeds. A guide to professionals applying participatory approaches in agrobiodiversity management, crop improvement, and seed sector development. Wageningen, Wageningen International, 83p.

Ibrahim M, Alaa M, Hamed E, Salah-Said A. 2019. Environmental SWOT Analysis for Agricultural Extension in North Sinai Governorate, Egypt. Turkish Journal of Agriculture - Food Science and Technology, 7(10): 15031508. DOI: https://doi.org/10.24925/turjaf.v7i10.15031508.2216

Kangas J, Kurtila M, Kajanus M, Kangas A. 2003. Evaluating the management strategies of a forestland estate-the S-O-S approach. Journal of Environmental Management, 69: 349 358

Metayer S. 2004. Vicia faba breeding for sustainable agriculture in Europe. Environmental Science and Natural Resources 5(1), 273- 282.

Mihiretu A, Asresu M, Wubet A. (2019). Participatory assessment of lentil (Lens culinaris Medik.) production practices in marginal dry lands of Wag-lasta, Ethiopia. Archives of Agriculture and Environmental Science, 4(3): 288-294, $10.26832 / 24566632.2019 .040305$

Ogwal-Kasimiro OJ, Wakulira M, Kiyini R, Mwebaze M, Yiga D. 2012. Dissemination of agricultural technologies: A new approach for Uganda. Paper presented at Third RUFORUM Biennial Meeting 24 - 28 September 2012, Entebbe, Uganda.

Sanghi NK. 1987. Participation of farmers as co-research worker: some case studies on dryland agriculture. Workshop on Farmers and agricultural research: Complementary methods, IDS, University of Sussex, July 1987, p26-31.

Shapiro J, Sanders FH. 2002. Growth, yield and quality response of faba bean varieties to different levels of N, P and K. International Journal of Agriculture and Biology 4 (3), 362364.

Shiferaw DE, Diriba MU, Gezahegn BE. 2013. Effect of Phosphate solubilizing Bacteria on Seed Germination and Seedling Growth of Faba bean (Vicia faba L.). International Journal of Agricultural Research, 8(3): 123-136.

Tafere M, Dessalegn T, Dessalegn Y. 2012. Participatory Varietal Selection of Faba Bean (Vicia Faba L.) for Yield and Yield Components in Dabat District. Wudpecker journal of agricultural research, 1 (7): 270-74.

Teame GE, Seid EP, Diriba LE. 2017. Participatory Evaluations of Faba Bean (Vicia Faba L.) Varieties in Enda Mekoni District, North Ethiopia. African Journal of Agriculture, 4(2):263-68.

Teklay A, Birhane T, Nega Y, Workineh A. 2014. The Prevalence and Importance of Faba Bean Diseases with Special Consideration to the Newly Emerging 'Faba Bean Gall' in Tigray, Ethiopia. Discourse Journal of Agriculture and Food Sciences, 2(2): 33-38. 
Temesgen A, Aemiro B. 2012. Genotype X Environment Interaction and Stability Analysis of Faba Bean (Vicia faba L.) Varieties in North Ethiopia. Libyan Journal of International Agriculture 3 (4), 195-200.

Tolessa TT, Keneni G, Mohammad H. 2015. Genetic Progresses from Over Three Decades of Faba Bean (Vicia faba L.) Breeding in Ethiopia. Australian Journal of Crop Science, 9(1): 41-48.
WOA (Woreda Office of Agricultural Development). 2018. The general agricultural and livestock basic information guide: Agricultural working report on: livestock and livestock characteristics, Niyere aqu, Abergelie, (Unpublished), p 12-13.

Yirga K, Zinabu N. 2019. Participatory Evaluation of Faba Bean (Vicia faba L.) Varieties for Yield and Yield Components in Wag-Lasta, Eastern Amhara, Ethiopia. East African Journal of Sciences, 13 (1): 7-14. 